\title{
NATO's Internal Deepening, Endurance, and Expansion: Economic Incentives and Gains as an Explanatory Complement to Realist Alliance Theory
}

Nikoloz G. Esitashvili

New Vision University, Tbilisi, Georgia, niesitashvili@newvision.ge

Félix E. Martín

Department of Politics \& International, Florida International University, martinf@fiu.edu

Follow this and additional works at: https://digitalcommons.usf.edu/jss

pp. $17-45$

\section{Recommended Citation}

Esitashvili, Nikoloz G. and Martín, Félix E.. "NATO’s Internal Deepening, Endurance, and Expansion: Economic Incentives and Gains as an Explanatory Complement to Realist Alliance Theory." Journal of Strategic Security 13, no. 3 (2020) : 17-45.

DOI: https://doi.org/10.5038/1944-0472.13.3.1828

Available at: https://digitalcommons.usf.edu/jss/vol13/iss3/2

This Article is brought to you for free and open access by the Open Access Journals at Digital Commons @ University of South Florida. It has been accepted for inclusion in Journal of Strategic Security by an authorized editor of Digital Commons @ University of South Florida. For more information, please contact digitalcommons@usf.edu. 


\title{
NATO's Internal Deepening, Endurance, and Expansion: Economic Incentives and Gains as an Explanatory Complement to Realist Alliance Theory
}

\begin{abstract}
NATO endured the end of the Cold War in 1991, its members deepened their commitment to the alliance, and it expanded considerably. Its survival fundamentally challenges the logic of realism, prompting two essential questions. First, is it possible to salvage realist alliance theory in the face of its apparent failure to explain NATO's continuing operation? This article contends that realism is repairable and salvageable in this context. Second, if realism is still a viable argument about NATO's endurance, how can it explain it? This article adds a complementary and still-missing explanation to realism based on economic incentives and gains. It argues that economic considerations such as the high cost and complexity to research, design, develop, and produce cost-efficiently modern, sophisticated, and technically complex weapon systems represented a substantial financial undertaking for NATO's great power members. The unparalleled economic burden prompted allies to pull resources together instead of seeking security unilaterally or through other alignment alternatives. The economic imperative of the modern defense industry is an essential and overlooked variable among realist and non-realist perspectives. Economic incentives affected in unprecedented ways the strategic calculus of NATO's great powers and, thus, causes their increased commitment to the alliance, its endurance, and expansion.
\end{abstract}




\section{Introduction}

Military alliance dynamics and theory rest on realims's balance of power assumptions. One fundamental presupposition in the realist paradigm postulates that states facing a common geostrategic external threat will form a military alliance to secure themselves, survive, and remain independent. ${ }^{1}$ Thus, scholars routinely challenge and criticize classicaland neo-realism for failing to account for the internal deepening, endurance, and expansion of the North Atlantic Treaty Organization (NATO) after the disintegration of the Soviet Union on December 25, 1991. In essence, its principal geostrategic threat and, admittedly in realism, one of the fundamental reasons for its formation and continued operation for well over four decades. ${ }^{2}$ As Mearsheimer remarked in 1990, "the Soviet threat provides the glue that holds NATO together." 3

Still more puzzling from realism's viewpoint and its attendant balance of power theory are two crucial historical outcomes. First, NATO great powers' lack of efforts to balance each other, the United States, or other rising great powers unilaterally or through alternative multinational military coalitions. This outcome is unlike earlier historical instances at the conclusions of the two World Wars in 1918 and 1946 respectively. 4 Second, NATO members' incremental commitment to the alliance caused a remarkable internal deepening of their collaboration and policy coordination during the post-Cold War period. These results are particularly prominent in regards to their defense and procurement policies. These confounding conclusions prompt two fundamental questions. First, is it possible to salvage realist alliance theory in light of the apparent failure to explain NATO's survival, deepening, and expansion in the absence of its geostrategic enemy or external threat? This article contends that realism is repairable and salvageable in this context. Second, if realism is still a viable argument about NATO's endurance, how can it explain it? This article offers an economic-incentive-driven alternative explanation to complement it.

In addressing the questions above, this article's purpose is three-fold: First, it advances a complementary (not competing) and hitherto-missing alternative explanation from within the realist paradigm. It adds to the fundamental premises of this school of thought, comprising several prominent variants such as Classical, Structural, and Neo-classical 
realism. This focus will help to explain NATO's remarkable endurance, deepening, and expansion since 1991. The analysis concentrates on the twenty-five years since the collapse of the Soviet Union. Second, the study articulates an economic-incentive-driven model, based on the nature and market-character of the modern and highly sophisticated defense industry. The article argues that economic incentives and gains promoted an intense and unprecedented level of commitment by the great powers to the alliance. Ultimately, such a level of commitment and collaboration eased NATO's internal deepening and, consequently, its endurance and expansion. Third, the essay broadly presents and examines available empirical evidence from the defense industry to substantiate the economic-based argument advanced here.

Now, it is necessary to clarify four fundamental points that the study does not aim to accomplish: First, it does not attempt to debunk other alternative explanations such as, for example, the central or hegemonic role played by the U.S. in NATO's endurance, or even constructivist arguments about the transformed institutional nature of NATO. Second, the study does not claim that economic interests dominate political and security calculations leading to NATO's survival. Nonetheless, as Mearsheimer asserts, "economic calculations are hardly trivial" considerations for nations-states. 5 Accordingly, the article demonstrates that economic incentives and gains also contribute to NATO's extended operation. Third, the study does not attempt to advance another economic theory of military alliance formation, operation, or termination. ${ }^{6}$ Fourth, it does not contend that NATO is a necessary condition for member states to achieve gains and secure international cooperation. That is, states do not need a formal military alliance to cooperate on weapons projects. Nonetheless, starting from the realist perspective and since the alliance remains operational since 1991, this article accepts NATO's perplexing endurance in the absence of a formidable external threat like the former Soviet Union was from 1947 until 1991. Thus, the scope of this article is to provide an additional, complementary, and reasonable explanation based on economic incentives and gains.

Accordingly, based on the three objectives outlined above, the first section contextualizes empirically and theoretically NATO's paradoxical endurance, deepening, and expansion. The idea is to frame the contention of this article. Second, an examination of realism in the context of NATO's 
survival follows the order of the article. This discussion flows from classical definitions of power, threat, and interest, and the ways in which these socio-political dimensions shape the alliance choices of states.

Short of outright rejecting realist arguments and, preferably, adding complementarity to realist alliance theory, the third section introduces and discusses the theoretical underpinnings of the political-economic dimension of power politics or Realpolitik. It expounds on the economic rationale for the endurance of the military alliance. Based on economic concepts and theory, the essay discusses several key theoretical components of the economic-incentive-driven model. These serve as critical building blocks of an alternative and novel economic explanation of NATO's continuing operation.

The economic angle emphasized in this article is a crucial theoretical aspect overlooked mainly by security and military alliance dynamics theorists and, thus, it is missing from political realism. This essay brings it back into the discussion. Thus, the fourth major section analyzes the evidence of the post-Cold War alliance dynamics, procurement policies of key member states, and the ways in which this evidence manifests itself in various multinational defense projects. The aim is to explain why NATO's great powers deepened their collaboration and continued their internal military commitment after 1991, even in the absence of imminent external threats. The fifth and final section offers concluding remarks from a realist perspective on this most intriguing historical development and theoretical puzzle.

\section{Historical and Theoretical Contextualization of NATO's}

\section{Paradoxical Endurance}

The unraveling of the Soviet Bloc began in Poland in June 1989.

Furthermore, massive protests throughout Eastern Europe, the collapse of the Berlin Wall on November 9, 1989, and domestic-level conditions operating inside the former Soviet Union, ultimately caused its collapse and ended the Cold War. Nonetheless, NATO perversely still endures despite the end of the Cold War and the disappearance of the Soviet Union-the principal rival and threat that, according to realist logic, prompted the military alliance's formation and justified its military and geostrategic operation until 1991. Further, well over a quarter of a century 
after the dissolution of the Soviet Union and the Warsaw Pact Treaty Organization, NATO intriguingly expanded its membership, and kept its internal structure and organization virtually intact. Also, it invested in new military capabilities, and engaged in a variety of new military missions. These developments deepened its members' commitment, and caused the redefinition of NATO's original geostrategic function and purpose.7

Some argue that NATO'S survival is not surprising. Instead, it is the result of U.S. political and military incentives and interests to maintain a degree of political and military control and governance over Europe and its allies. ${ }^{8}$ Others claim that the Europeans and the North Americans never indeed accepted the collapse of the former Soviet Union and its replacement by the Russian Federation as the absolute disappearance of the external geostrategic threat to NATO's allies. ${ }^{9}$ For example, based on constructivist assumptions, Pouliot explains the prolonged tension between NATO and Russia after the end of the Cold War and into the late 1990s. This group of scholars contends tensions became particularly acute as President Vladimir Putin's ascendance as a powerful autocrat materialized and expanded in Russia. Hence, the need for maintaining NATO in place. ${ }^{10}$

Moreover, other experts claim that, as an institution, NATO enables an exchange between some European members seeking offensive capacity and the United States pursuing legitimacy from its European partners. The enablement of the terms of this exchange provides NATO its reason or justification for existence. ${ }^{11}$ In addition, Sweeney defines NATO as an institution that can adjust to changing history. ${ }^{12}$ Even others contend that the abrogation or survival of a military alliance, like NATO, is "sensitive to changes in core supporting domestic coalitions," but the termination of alliances is less likely among democratic than among nondemocratic states. Hence, NATO survives. ${ }^{13}$ From the institutional perspective, others focus on the constitution and re-constitution of NATO's roles from its inception to its anomalous survival since 1991.14

On a purely structural perspective, some see that the collapse of the Soviet Union transformed a bipolar world into a more fluid multipolar security system that ushered in multiple, flexible military alliance opportunities among the Russians, Chinese, and other potential international state actors against the United States and the other NATO great power allies. 
These outcomes would have been particularly the case, had the military alliance been disbanded as were the cases in previous historical instances such as the Triple Entente and the Central Powers after the First World War in 1918, and the Allied Powers that defeated the Axis Powers after the Second World War in 1946.

Based on historical precedence and realist theoretical reasoning, many experts believed that NATO's members would dissolve the alliance. The assumption was that, after the end of major systemic or general (hot or cold) wars, the triumphant military alliance members would usually disband the alliance based on changing great powers' national interests, the realignment of powers, and the absence of common systemic threats. Consequently, some in this group question the future of NATO. ${ }^{15}$ From a constructive theoretical standpoint, others still explain NATO as an unfolding vision and practice that may transform how "we think about security logic in general, European security in particular, and European alliance politics specifically."16

It is the latter interpretation, albeit from different theoretical assumptions and perspectives, that comes closest to the explanation comprised in this article regarding NATO's internal deepening and, consequentially, to its endurance and expansion. This interpretation is a puzzling political event in its own right. Additionally, though, it is counterintuitive, mainly, when viewed from a realist position and the internal logic of its theories on military alliance dynamics. First, as discussed above, NATO's central geostrategic rival-the Soviet Union-disappeared and, thus, with it the need for a countervailing military alliance. Second, China and Russia have been individually incapable of counterbalancing and threatening NATO's conventional forces in Europe and North America for most of the last twenty-five years. Finally, the end of cold or hot wars and the absence of a subsequent identifiable threat suggest the dissolution of military alliances as history extensively reveals. Unquestionably, NATO's deepening, expansion, and endurance are crucial aspects worth exploring further and comprehensively in terms of historical, geopolitical, strategic, and theoretical ramifications.

Several alternative explanations for NATO's endurance are part of the literature. They comprise multiple elements such as the political interest of the United States to maintain its global dominance, institutional 
endurance, and reinvention of NATO's purpose and operation, supranational regional governance dynamics, and cultural and ideological affinity, to name a few. Notwithstanding the contributions of these alternative explanations, none attempts to complement or enhance realism's age-old balance of power dynamics and its attendant military alliance theory, which would have predicted NATO's dissolution after 1991 and the inception of a new realignment process among former NATO members and other great powers. Since this was not the outcome, as posited by the theory, how does realism explain NATO's deepening, endurance, and expansion? ${ }^{17}$

This article repairs and expands realism and its internal reasoning about the determinants for the extension of military alliances. It accomplishes this goal by explicitly adding an economic-based missing link to its set of assumptions and logic. Accordingly, it shows an economic rationale that has stimulated decisions by the United States, Canada, and the great European powers to deepen their military collaboration and commitment within NATO. Thus, in addition to the paramount security, political, institutional, ideological, and geostrategic considerations, economic interests, and incentives complement and support members' commitment to the alliance, as argued in this work.

Burden-sharing among NATO members was never easy or smooth. Nonetheless, the political economy of the modern defense industry in terms of technology research, design, development, and cost-effective production is an essential and missing dimension in the general realist paradigm. Hartley and Sandler discuss and analyze the burden-sharing problem by NATO members. ${ }^{18}$ The great European powers and the North American NATO members have gained from remaining involved in the alliance, deepening their internal commitment, and allowing for its endurance and expansion. This argument is the point of entry of this article into the discussion about NATO's survival and expansion. It complements other alternative explanations in the literature in International Relations and Security Studies. Instead of challenging other schools of thought and competing explanations, this essay focuses on enhancing the explanation of the alliance's functional duration.

NATO's endurance and expansion are solid, observable empirical facts. It is difficult, however, to explain the reason(s) for its progressive internal 
deepening, which, as this article argues, may ultimately be the cause of these actual outcomes. In order to provide empirical justification for this essay, it is necessary a succinct review of the preliminary evidence suggesting NATO's internal deepening by its members' economic incentives and commitment to the alliance. First, the United States and other allies are cooperating in multiple defense programs, exceeding several billion dollars individually over the last several years. Second, the United Kingdom and the United States are also vital partners in terms of defense industry cooperation and military materiel sales. They engage in several common equipment programs. Third, France and Great Britain have multiple military cooperation programs. They are already building a Future Combat Air System, which is due to be active in 2030.

These materials and technical multinational, cooperative development projects outlined above beg the following questions: Why do NATO's great powers - the United States, Great Britain, France, and Germany-continue to cooperate intensively in military matters? What are the strategic imperatives that call for the alliance's internal deepening and its ultimate endurance and expansion? As discussed above, traditional political and geostrategic justifications for the formation or, in this case, maintenance, and operation of a military alliance have been tenuous for most of the last quarter of a century. Starting from a realist perspective, except for the expected disappearance of the Warsaw Pact Treaty Organization, it is intriguing that the end of the Cold War did not cause a significant rearrangement and realignment of all military alliances. It appears as if great power politics since 1991 descended to a secondary plane in strategic security considerations. Alternatively, has it?

The analysis of this article builds on the following assumptions:

Realpolitik considerations today are as relevant as ever; that great powers have not redefined their strategic security interests significantly; and that the logic of power politics is still one of the vital driving forces in contemporary world politics. Nonetheless, as discussed above, there have been essential and unaccounted developments in the political economy of the defense industry, which have swayed NATO's great powers to deepen their internal military commitment and multinational cooperation after the Cold War. The peculiarities of the political economy of the modern defense industry have made it exceedingly expensive and technically challenging for most NATO's great powers to exit the military arrangement 
and, instead, pursue its security unilaterally or via an alternative multilateral military cooperation pact or a different realignment of systemic forces. It is essential to explore if and how this exceptional development in alliance dynamics renders obsolete the realist paradigm and its attendant theories.

Classical realism and neo-realism are predominantly silent on how the new defense industry's political economy affects the power capabilities of states, their calculations, and alliance politics and choices among great powers. Instead of emphasizing the economy and the accumulation of wealth as the primary state's objectives, realism traditionally underscores maximizing and maintaining security, prestige, supremacy, and even domination. ${ }^{19}$ The attainment of these objectives does not suggest, however, that realists neglect the economic dimension of politics completely, particularly of international politics. While "realists are not in it for the money," they do appreciate the economy and the importance of economic factors. ${ }^{20}$

Accordingly, neorealist, for example, Kenneth Waltz, in his Theory of International Politics, devotes an important part of his book to examine the structural effects on the economy, but, regrettably, nothing to the economic effects on the structure. ${ }^{21}$ Notwithstanding such mild neglect, the newer realist iteration, neo-classical realism, addresses, and incorporates the domestic economy prominently, the political economy of national security, and economic statecraft. ${ }^{22}$ The present work fills the partial gap in realist theorization about modern military alliance dynamics. In addition, it demonstrates that the political economy of the defense industry is an important variable that can potentially affect the traditional calculations and power of states. In turn, economic considerations and incentives may transform in unprecedented ways the logic of modern military alliance politics among great powers. The economic dimension may complement realist theories of military alliance dynamics.

\section{Foundations of Military Alliances: Balancing Power, Threats, or Interests?}

Based on realist assumptions, the core objectives of any state in the international system range from basic survival, security, and independence to acquire and increase power and status. States count on a 
range of strategic options to accomplish these unilateral preferences. These include balancing efforts, bandwagoning, offshore balancing, buckpassing, and chain ganging. Balancing and bandwagoning are the most germane in NATO's case. The first option is the most traditional way by which nation-states protect their security. Accordingly, they accomplish it through either self-help or via multilateral military arrangements to countervail the threat from a rising expansionist and revisionist state. Second, bandwagoning is the strategy when states join a powerful state rather than oppose it. This strategy resembles more closely NATO's alliance structure and dynamic since 1991. Nonetheless, bandwagoning appears in two versions in the literature. Thus, this study, as others should too, declines to accept it grossly and without further refinement. Subsequently, the discussion turns to NATO's historical incongruity in reference exclusively to realist military alliance theories focus on bandwagoning and balancing processes.

First, Stephen Walt argues that some states bandwagon because they lose hope of balancing the aggressor and, instead, ally with a stronger foe to gain, at least, something from wars. Walt suggests that bandwagoning is a dangerous strategy, though, and states will bandwagon only if they cannot balance a threatening enemy. Weak states are more likely to bandwagon with the threatening state because they may be too weak to balance them unilaterally. On the other hand, strong states have a better chance of affecting the outcome of the conflict and are more likely to balance than to bandwagon. ${ }^{23}$ Walt's bandwagoning argument in its current form does not explain why states would continue to be part of an alliance in the absence of either a general or immediate threat, as is NATO's case since the end of the Cold War. Admittedly, though, Russia and China could at some point rise sufficiently to threaten European and North American countries. At present and over the last twenty-five years, however, both great powers lack individually or collectively the necessary might to pose a significant conventional threat to the Europeans and the North Americans. In this sense, first, it is even more intriguing to confirm that the NATO alliance continues to exist. Second, that the Europeans bandwagon with the most powerful actor in the victorious alliance-the United States-rather than dissolve the alliance after the end of the Cold War as were the historical cases after the end of the First and Second World Wars' Triple Entente and the Allied Powers alliances, respectively. 
Second, Randall Schweller may provide a clue as to why powers could ally even if the threat to their security is tenuous or nonexistent. He introduces some modifications to the bandwagoning alliance strategy proposed by Walt. He suggests that Walt mistakes bandwagoning with capitulation, and falsely attributes this strategy to the coercion of the weaker side by the strong. According to him, Walt's bandwagoning falsely assumes that states only look for power to achieve security. This interpretation is possible because Walt bases his argument on the assumption that "states value more what they have than what they covet." 24 Schweller counters that some states-the so-called revisionist states-are not satisfied with their position and, thus, care to increase their power rather than maintain security. 25 Like other theories, Schweller's balance-of-interest alliance theory cannot explain why the United States and the Western European states continued their close military cooperation despite the end of the primary, geostrategic threat in 1991. Schweller's variant, nonetheless, does explain why the United States and the Europeans would align with each other against an external threat: They have common interests in preserving the existing status quo. As he argued against Walt's variant, states sometimes join an alliance hoping to gain something rather than to defend from a real threat. Although it does not explain why the NATOs great power members continued cooperating, deepening their collective commitment, and expanding the alliance, he does introduce the possibility of states aligning in order to pursue gains beyond traditional security and power interests. These theoretical gaps and Schweller's suggestion that states may bandwagon or remain in an alliance to pursue gains beyond security suggest that some other causes for military cooperation remain unaccounted for and, thus, are worth pursuing in this study.

The political-economic argument advanced in this article is one of these unaccounted causes, and it will nicely complement Schweller's bandwagoning variant. Some political-economic considerations and incentives often motivate the individual decisions of NATO's great powers. Expectations of economic gains, for example, from the prospect of future trade benefits, may prompt the behavior of states. ${ }^{26}$ This conclusion is seldom part of the reasoning for military alliance formation, operation, and maintenance. For example, one can argue that genuine pecuniary interests and incentives primarily motivated the vast military coalition of 35 countries and the United States that fought in the Gulf War against Iraq's Saddam Hussein regime from 1990-1991. Undoubtedly, some 
countries like Saudi Arabia and other small Gulf states ultimately joined the coalition out of fear and for security objectives. Nonetheless, there were number of other states who joined the alliance to pursue real economic gains. This explanation suggests economic incentives as gains are part of the fundamental justification and explanation for countries to join or remain in a military alliance. This angle is consistent with the basic logic of bandwagoning into a military coalition in exchange for economic incentives and gains expounded by Schweller.

This article maintains, as Mearsheimer contends, that when security clashes with economic motivations, security concerns prevail. This work does not argue against this basic tenet of realism. On the contrary, a fundamental assumption of this study is that the compatibility of security and political interests must precede any economic-driven cooperation in defense-related matters. That is, when security and political considerations are relatively harmonious, then the tendency for nationstates to cooperate in joint military-production projects to attain economic gains increases considerably. Given the relative compatibility of interests among NATO states, they have been cooperating in defense-related projects, motivated in part by economic calculations.

In addition, as Monteiro argues, this work recognizes that, depending on the system's polarity, the type, and nature of conflicts and threats vary accordingly. Independent of the changing conflict-provoking dynamics, given different polar configurations over a quarter of a century, economicdriven defense cooperation among NATO's great powers members increased steadily since the end of the Cold War. ${ }^{27}$ The prevalence of multinational defense projects among NATO members suggests that variation in systemic polarity and the type of conflicts as the system changed from structural unipolarity to multipolarity suggest that economic-driven military cooperation warrants further scrutiny.

In the following section, the article examines the interactive dynamics of processes like economies of scale, economies of scope, and several other economic factors that are at play in the modern defense industry. The overall impact these economic processes on alliance deepening, endurance, and expansion ought to include it as an additional explanatory perspective for NATO's surprising survival in the absence of an external threat. The article turns next to the discussion of the theoretical 
components of this argument and their attendant individual logics subsequently.

\section{Economic Rationale: The Theoretical Building Blocks of the Model}

Since the end of the First World War in 1918, technical research, development, production, and distribution of modern military technology became exponentially hi-tech and costly. This process has mainly been a particular lot of a small group of countries that are steep in scientific and technical expertise. In turn, the scientific, technical, and industrial communities in these states have made available higher levels of technical sophistication in weapons systems to the national armed forces. However, the availability of these technologies comes at an exceedingly high economic cost. Thus, the defense procurement policies of all states have been severely affected, calling for new, imaginative ways to keep the armed forces modernized and at pace with weapons systems developments and security needs.

Even countries enjoying a relatively wealthy international status, like some European states and, explicitly, Canada, as revealed by its long-drawn budgetary, political process to replace its aging fighter planes fleet with the new, highly sophisticated and expensive F-35 plane, have been forced to be creative and to reinvent how to protect themselves in resourceful ways. One alternative has been to remain as a member of NATO-a military alliance that belongs to a bygone period. While there may be sound security, political, ideological, and geostrategic justifications for opting to keep NATO alive, there is, nevertheless, an equally robust economic rationale for these NATO members to maintain their military and defense collaboration.

\section{Economic Incentives and Gains as Driving-forces for Cooperation in Defense-Projects}

The economic imperative is an essential and primarily overlooked determinant that affects and transforms in an unprecedented way the strategic calculus of great powers within NATO. Thus, the argument comprised here assumes that the opportunity cost to maintain and increase technical sophistication in weapon systems creates substantial incentives for NATO's great power members to remain active and deeply 
involved in this military alliance. Once internal commitment materializes as the result of political-economic interests, the endurance and expansion of the alliance ensue in unprecedented fashion.

This section introduces several critical economic concepts that taken together can help to explain states' decisions to stay in a military alliance and continue to cooperate in security matters, even beyond the disappearance of the original strategic objective that fueled the formation of the coalition. Economies of scale, scope, learning-by-doing, and research and development costs, among other concepts, provide the economic building blocks and rationale for this explanatory model. This essay defines each of these concepts and their respective theoretical economic logic and shows how each contributed to the political-economic argument outlined in this article for NATO's surprising internal deepening, and its consequential expansion and endurance. Further, bringing back in the economic argument will enhance and complement the realist theory of military alliance dynamics. The essay distinguishes this as a realist theory. It contends that the nature and purpose of multinational coalitions range from purely security objectives-defensive or offensive-to economic, corporate, political, and diplomatic. The nature of military alliances is less forgiving than other possible multilateral collaborative modalities. Thus, the article calls attention to the theory of military alliance dynamics by underscoring the unique defensive and offensive operations of cooperative entities such as NATO. ${ }^{28}$

Realists discuss political-economic considerations mainly under the rubric of internal and unilateral balancing. According to them, states engage in internal balance when they augment their capabilities by increasing economic growth and military spending. In turn, natural resource endowments, and demographic, economic, military, and technological capabilities determine the economic potential of countries. However, with political-economic factors, a different logic ensues. Missing from previous theoretical positions about military alliance dynamics is a simple but grossly overlooked economic notion. That is, in cooperation with each other concerning weapons research, design, development, cost-effective production, and procurement policies, nation-states may be able to achieve more capabilities while using fewer individual resources. Consequently, it makes economic, even if, perhaps, not political sense for states to cooperate to reduce such costs, provided, of course, their national 
political and security interests are a priori compatible. This work expounds below each of these political-economic components or building blocks and interprets their particular relevance for a political-economic alternative explanation of military alliance dynamics.

\section{Market Imperfections}

Scholars criticize classical economic theory because it assumes that markets are perfect. However, as demonstrated, in specific scenarios, the allocation of goods and services on markets may be inefficient and imperfect. These market failures are situations when the actions of agents to increase their utility might not lead to the optimal outcome. ${ }^{29}$ There are many reasons why market failures occur. One of the most important has to do with the nature of markets. In specific markets, participants can possess market power and preclude other beneficial transactions from taking place. Inefficiencies can arise due to limited competition, for example, in markets where actors are monopolies or monopsonies. ${ }^{30}$ In monopolistic markets, an agent will provide goods or services below the optimal utility level for customers to keep profits high. Monopolies arise and persevere when barriers to entry in the market are high. Importantly, first entrants might have an advantage like diminishing costs as the number of their output increases.

\section{Economies of Scale}

Economies of scale are among the most frequent market imperfection cases. Economies of scale imply a change in the efficiency of production, given changes in production capacity, volume, or quantity. ${ }^{31}$ Often, economies of scale originate because of fixed and variable costs, which decrease per unit of production as the volume of production increases. In some businesses, increasing the speed of conducted work decreases fixed costs. Economies of scale may originate due to multiple reasons. For example, establishing long-term contracts may decrease the purchasing costs; allowing managers to specialize can increase the speed and quality of their work; borrowing in large quantities may decrease the interest on loans; advertising large quantities of goods instead of just one, employing more efficient technology. In the end, in each of these scenarios, the average cost of production decreases. 


\section{Fixed Costs and Economies of Scale}

Often economies of scale exist due to substantially fixed capital expenses. In turn, unit cost decreases as the volume of production increases. The fundamental characteristic of fixed costs is independent of their frequent and extensive use. They do not fluctuate. Building factories, warehouses, and investing in equipment are all examples of fixed costs. Of course, there are current costs associated with these assets, and some of them will likely vary (variable costs), at least in part, according to the level of output-for example, maintenance and security. ${ }^{32}$ However, such costs are minimal compared to the fixed expenses incurred by companies.

Substantial economies of scale are characteristic of industries with substantial fixed costs. Industries, which are capital intensive, are usually the ones with high fixed costs. Examples of such industries are railroads, aircraft production, semiconductors, and information technology, to name a few. In these industries, only if the quantity of production is large enough will unit costs reach the minimum level possible. It is necessary to have massive investments in production facilities, measured in billions of dollars, to attain such levels of output. 33

\section{Economies of Scope}

Panzar and Willig advanced the notion of economies of scope. With economies of scale, the efficiency of production is a direct consequence of the volume of production. With economies of scope, however, efficiencies stem from a variety of products. In other words, diversification of production achieves critical economic benefits. However, diversification of product base is only possible if the producer makes frequent use of some knowledge, expertise, or even a particular asset. 34 An example of economies of scope is a company that promotes a few different products, reaching more people with the same amount of money spent as compared to the scenario when different companies specialize in the production of particular goods. Economies of scope allow the company to cut down the costs of advertising and branding goods. Usually, economies of scope are possible when companies start to share separate functions, for example, finance, and advertising. It also happens when a company sells one of its products next to another and can use specific outputs as inputs for others. 35 


\section{Learning-by-doing}

Learning-by-doing implies increasing efficiency using practice and perfection. The process of learning implies that companies think, realize their problems, and then take measures to solve them. Companies might learn to use their equipment better. Dynamic programming and strategic planning are fields where learning-by-doing is of primary importance. In learning-by-doing workforce increases its efficiency by repeating the same process endlessly. Kenneth Arrow promoted the idea when he coined his endogenous growth theory incorporating innovations and technical change into the classical explanation of economic growth. Arrow used the learning-by-doing to denote learning inside the company. ${ }^{36}$

Lucas Bretschger showed that there are increasing returns associated with human capital. According to him, training or, in other words, learning is fundamental in building human capital.37 Various economists have shown that learning-by-doing leads countries to greater specialization. Lundberg studied the Horndal iron factory in Sweden. He observed that the productivity of the factory increased by 2 percent per year, although it had no new investments. Wright and Middleton show that in the aircraft industry, labor productivity and output have increased with time independent of scale effects. 38

The literature in engineering and management supports the notion of learning-by-doing, which demonstrates the fact that increases in aggregate output have a dampening effect on unit costs. Although experts within the aircraft industry knew about the effects, Wright was one of the first who discussed the phenomenon in his analysis of aircraft manufacturing. These analyses established that in the 1950s, the U.S. government was purchasing boats and planes from shipbuilders and aircraft manufacturers, already incorporated in the budget. 39

\section{The Costs of Research and Development}

Both military and civil aerospace costs are tremendous, and the costs are growing at an exponential rate. ${ }^{40}$ The historical cost trend arises from technical progress in each generation, with governments striving to purchase the latest products to have a competitive edge. Augustine forecasted that the costs of military production would increase to the extent that all resources in the defense budget would go to acquire just one 
aircraft. Both Navy and Air Force would have to share this single aircraft 3.5 days each week because they could not afford more. According to Augustine, the British military would reach the same point a bit earlier than the United States, and countries with smaller defense budgets would take even less time. Partly, the rising costs of producing military equipment cause this, while military budgets fail to keep up with increasing costs. ${ }^{41}$ Augustine's prediction centers on rising costs in hightech equipment. He shows that the costs of aircraft have grown fourfold per decade. This trend is similar to the procurement and acquisition of helicopters, ships, and tanks, as well as commercial aircraft. Ships and tanks costs decreased by a two-fold factor per ten years. ${ }^{42}$ These trends led to suggestions of an eventual single ship navy, a single tank army, and Starship Enterprise for the air force. 43

\section{Analysis of the Post-Cold War NATO Dynamics}

The principal purpose of this article is to find and articulate a sound answer to the following central research question: Why did NATO's great powers continue their cooperation in the absence of a direct and formidable external threat? The answer hinges on economic considerations and incentives as gains, leading to significant savings in the research, development, and production functions of military materiel and operations. After the Cold War, in the absence of an external geostrategic threat, NATO members did not need to spend as much on expensive and sophisticated weapons and on keeping large operational infrastructures, and specialized personnel. Regarding research, design, development, and efficient production, NATO countries let military industries to consolidate, engage in trans-border, friendly mergers or economic cooperation, take advantage of economies of scale, scope and learning by doing, and share in research and development costs. It appears that for the next twenty-five years after the collapse of the Soviet Union political competition among NATO's great powers yielded to more pragmatic economic imperatives and calculations. The balance of the analysis comprised here centers only on NATO's great powers members and their weapon systems collaboration. Thus, it excludes the European-Union-based Permanent Structured Cooperation (PESCO) program. This entity promotes multiple defense collaboration efforts among twenty-five member states. 44

This article analyzes a mixture of qualitative and descriptive quantitative evidence to investigate the main question. The focus is on the behavior of 
the most important members of NATO, such as the United States, Canada, France, Great Britain, and Germany during the post-Cold War period. The study attempts to shed light on the presence or absence of external threats and the sustained efforts by NATO's great power members to continue their military, multinational economic, technological, and strategic cooperation. Accordingly, this section examined the empirical bases for NATO's great powers to continue and deepened their military cooperation internally after the Cold War despite the absence of external threats. The aim is to test the following hypothesis: Cooperation in military production of states, with compatible or harmonious national political and security interests, positively relates to the existence of market imperfections such as economies of scale, scope and learning-by-doing and escalating research and development costs, in the absence of external threats.

Several experts have written about economies of scale, economies of scope, learning-by-doing, and other economic imperfections related to military production. Harold Asher noted, "the learning curve tended to apply to airframe production....with unit costs declining in a fairly predictable pattern as production expanded."45 Malcolm W. Hoag suggests that prominent production economies of scale do apply with particular frequency in military applications. ${ }^{46} \mathrm{He}$ argues that this is why "concentrated sources of supply tend to predominate,"-meaning that instead of many factories and producers, there are just a few that produce in large quantities. He illustrates the point with the example of F-iii (TFX), designed to be the advanced tactical fighter-bomber for both the United States Navy and the Air Force. Hoag concludes that the same logic applies to space programs. 47

Sandler and Hartley suggest that scale economies per se may have been only a modest influence on the structure of the defense industry in the past, though the evidence was more convincing for learning economies and their impact. Since the 1990s, however, scale economies had a significant impact as well. $4^{8}$ Dunne suggests that governments now appear more sensitive to the extra cost incurred by small national production runs (and the high technology nature of some manufacture) and more receptive to the argument that "economies of scale need to be met through international collaboration and industrial restructuring."49 
The analysis of U.S. economies of scale and scope at a time of shrinking demands led to a massive wave of mergers and acquisitions in the $1990 \mathrm{os}$. According to Markowski, the degree of cross-sector diversification among the most significant defense firms suggests that they perceive and value such economies. $5^{\circ}$ According to Dunne, a significant driver of economic restructuring is the growing trans-Atlantic nature of the defense industry. The process is, on the one hand, the result of European companies' aspirations to become major players in the U.S. market. On the other hand, according to Bitzinger, it is the United States' acceptance that "interoperability requirements, the benefits of cooperative defense programs, and an increasingly global industrial infrastructure require that the [U.S. DOD] be prepared to accept the benefits offered by access to the most innovative, efficient, and competitive suppliers worldwide."51

Various views summarized above point to one critical development: There are clear indications that since the end of the Cold War, cutting military costs became one of the major concerns for NATO members. Since the end of the Cold War, NATO members have not faced comparable external threats and, thus, have not required high scale production. Some firms could not keep up with reduced demand and exited the market. Others consolidated their operations and expanded their markets internationally to improve their capacity to remain in business. Importantly, though, NATO members collaborated and produced general orders, which allowed them to take advantage of scale, scope, and other economies, and to cut down production and overhead costs. By cooperating beyond immediate needs, these countries gained by saving from specialization in research, development, and production costs of defense materiel.

\section{Rising Costs of Sophisticated Weapons and Economic Incentives for Collaboration}

Expensive military technology and rising costs create a vital rationale for states to engage in military cooperation, namely, collaborative projects. Collaboration is particularly crucial because substantial fixed costs and small national orders make it too costly for states to have national production. Large international orders would allow the average cost of production to fall over larger volumes of output and make new technology affordable to collaborating nations. Moreover, rising costs make it impossible for any single nation in Europe to produce some future generation of military equipment on their own, for example, sophisticated 
fighter and bombers planes. In this sense, only a handful of combat aircraft companies compete for national contracts to replace aging aircraft. The Canadian debate about replacing its aging fleet of $\mathrm{F}-18$ Hornets is a clear illustration. $5^{2}$ Production of a new model will necessitate enormous resources. These could promote simultaneously the development of a future generation of combat planes through collaborative projects. Even advanced technology, such as unmanned air vehicles (UAVs) will be costly.53 Europeans will have to choose between increased collaboration and importation from other nations, which can afford large batches of production, such as, for example, the United States.

The study assessed collaboration gains following the square root rule. The rule implies that the costs of current projects compared to single-nation production increased by the square root of the number of participants. With four nations, the costs of developing a project would be twice as much as doing it alone. With the two nations, the costs can amount to 1.4. However, the partners share these additional costs so that each nation has lower development costs compared with a single national venture shouldering the entire program singly. 54 Although the aggregate costs increase due to cooperation, costs per nation decrease, which allows them to partake in the development of technology that they would not afford on their own. Pugh also shows that collaboration increases development costs as the number of nations rise. With two nations development costs being about 1.5, with three nations by about 1.8, and with four nations about 1.95 of single-nation projects. It is important to take into consideration, though, the fact that along with the drop in development costs per country, the increase in output affects the costs negatively. In general, the output doubling should result in a reduction in unit production costs of up to 10 percent. 55 Below, there are few examples of current military projects in which NATO's great powers have cooperated extensively since the end of the Cold War.

\section{NATO members' Common Weapon Projects}

Decreased economic costs provide significant incentives for states to cooperate. These are expenditures that take place during research and development (R\&D) and production processes. Collaborating nations can share R\&D costs, and they can achieve economies of scale and learn through increased production. For example, if two nations were intending to develop a similar high-tech weapon, which would cost them billions of 
dollars in research, they would be duplicating their resources if they invested in R\&D separately. Additionally, they would fail to take advantage of economies of scale, which comes with larger batches of production. Common projects would allow nations to save considerable resources. If all remains unchanged, two-nation collaboration with equal sharing will save half of the development costs for each nation in the example, and savings in unit production costs from a larger output. ${ }^{6}$ For instance, the doubling of output in aircraft production from 300 to 600 units might lead to savings in unit production costs of some 5 percent. If a single aircraft costs about 50 million per unit, savings are 2.5 million per unit. Twonation collaboration would avoid duplication of resources and save little over 5 billion for each nation. 57

The Typhoon plane program is the top multinational project among NATO's European members. The cost of development of the plane is over 54 billion Euros. Moreover, the Typhoon project has affected about a hundred thousand jobs in over four hundred European companies. Britain received 40,000 of these jobs, with Spain obtaining 25,000, and Italy and Germany about 20,000 each. A large part of these jobs is highly skilled in creating significant externalities for the rest of the economy. Skills from Typhoon production are transferable to many other industries as well. Typhoon scores more highly on gains from scale and learning through combining. $5^{8}$ This result is an important spillover effect. Technologies developed for defense will lead to advances in other industrial areas. The literature often overlooks this economic benefit.

Substantial economies of scale characterize aircraft production. Gains from production augmented as the quantity of production increased exponentially. Typhoon production benefits from learning with an average 85 percent learning curve and typically a 90 percent learning curve for combined labor and other operations.59 On Typhoon, learning was substantial over the first 60 units. Both Typhoon and Airbus have significantly improved the learning scale compared to previous generations. This example suggests that European aircraft production continuously improves in the learning scale, which manifests itself in productivity improvement and a downward shift in the average cost of production. 
The Typhoon brings significant industrial benefits. It allows the European aircraft industry to remain competitive, but also, allows Europeans to remain independent and feel secure in case of conflicts. ${ }^{60}$ Some critiques claim that Typhoon remains more expensive compared to other aircraft. Data confirms the criticism. Typhoon is about 20-60 percent more expensive than, for example, French Rafale. On a unit total cost basis, the French Rafale is about 10 percent less expensive than the Typhoon while the Swedish Gripen is about 50 percent less expensive. ${ }^{61}$

In response, it is crucial to note that comparing only prices confuses rather than clarifies. Prices say nothing about the operational efficiency of the aircraft. The Typhoon is a superior aircraft to the French Rafale. R\&D costs for the Typhoon are around $\$ 23.5$ billion, and the Rafale is about $\$ 21.9$ billion. The Typhoon is more expensive than the Rafale. However, four states share the R\&D costs of the Typhoon. France incurred R\&D costs solely. The Gripen costs about 6-8 billion Euros. However, it is smaller and more basic, with many combat disadvantages. The Typhoon has significant combat advantages over both the Rafale and the Gripen. ${ }^{62}$ The price and battle effectiveness data in Table 1 demonstrate that the Typhoon is the best combat plane among European produced planes.

Table 1. Relative Combat Effectiveness

\begin{tabular}{ll}
\hline Aircraft Model & Combat Effective Percentage \\
\hline F-22 & 0.91 \\
\hline Typhoon & 0.82 \\
\hline F-15F & 0.60 \\
\hline Rafale & 0.50 \\
\hline F-18E/F Super Hornet & 0.25 \\
\hline F-16C & 0.21 \\
\hline F-18 Hornet & 0.21 \\
\hline
\end{tabular}

Source: Authors

Note: Combat effectiveness rating of 1.0 means that the aircraft will always win a combat engagement; 0.5 means that it has an even chance and less than 0.5 means that it will usually lose.

Other examples of collaborative projects in NATO also confirm that joint production brings considerable benefits. Collaborative development compared with national alternatives can be about 140 percent for two nations (for example, Merlin helicopter), 161-179 percent for three nations (for example, the Tornado), and almost twice as high for four nations (for example, the Eurofighter). Despite higher aggregate development costs of 
collaboration, each partner only bears its share of these costs. Consequently, costs savings accrue to the nations involved in collaborative development work. Western Europeans are also cooperating in the production of missiles through a company called MBDA. The collaboration became highly successful and prosperous to the point that MBDA is now a primary competitor of one of the major global missile company, Raytheon, from the United States. Besides, the English and French have cooperated in the Storm Shadow missile project. Similarly, the Meteor air-to-air missile is showing promise with the United Kingdom acting as the lead on a six-nation international program, also involving France, Germany, Italy, Spain, and Sweden.

Logistical support can also bring substantial economic benefits. The United Kingdom, Netherlands, Belgium, and France have been cooperating in the logistical support of Spey, Olympus and Tyne marine engines. According to rough estimates, such cooperation has saved participating nations about 30 percent in maintenance services. The United Kingdom and the United States benefit considerably from their cooperation in Multi-Launch Rocket System and the Tomahawk Land Attack Missile. They have benefited from the economies of scale through joint purchasing of spare parts and shared maintenance facilities. ${ }^{63}$

Western Europeans have successfully cooperated in other helicopter and missile programs. Among them, the NH9o helicopter is essential. The NH9o helicopter is a four-nation collaboration to develop and build a medium-sized multi-role military helicopter. The manufacturers of the helicopter are N.H. Industries (France and Germany), AgustaWestland, and Fokker Aerostructures. North Atlantic Treaty Organization Helicopter Management Agency (NAHEMA) manages the program for participating NATO members. There are six assembly lines in locations in France, Germany, Italy, Finland, Spain, and Australia. This multinational program sold in 2011 five hundred seventy-three helicopters. European collaboration in helicopters created two industrial groups, competing against the U.S. helicopter industry.

The United Kingdom's Department of Defense estimates that collaboration with partners in research brings benefits almost five times the original investment. Collaboration with partners provides access to the necessary technology, saves duplicated costs, and, allows efficient management of a 
limited budget. The U.K. Department of Defense spends little over 40 million pounds on collaborative programs with other nations, less than 10 percent of its defense budget. However, according to their estimate, they obtain technology worth approximately £200 million- a 5:1 return on its investment. 64

\section{Other Collective Military Technology Collaborative Projects}

Helios 1: The Helios is a military reconnaissance system launched in 1995. The French, Italian, and Spanish governments funded this project. The Helios-1A and Helios-1B are two optical satellites, the first one launched in July 1995, and the second one within a four-year interval, which can acquire high-resolution images of any point on the globe. The French Ministry of Defense is responsible for the management of the satellites. Belgium, Spain, Italy, and Germany retain access to the imagery. Helios1A was operative until 2012, while Helios-1B lasted for four more years. ${ }^{65}$ France funded approximately 80 percent of the project, which sums to a little bit over $\$ 1.2$ billion. Italians make up about 15 percent-about $\$ 240$ million. Spain covers the rest of the expenses-close to $\$ 119$ million.

The Helios 2 comprises Helios 2A and Helios 2B. Both satellites serve military observation purposes. France, Belgium, Spain, and Greece cooperated in the creation and launch of the satellites. Helios 2A launched in 2004, and Helios 2B followed five years later. ${ }^{66}$ The Helios 2 is an improved version of Helios 1 satellite with improved optical sensors and operation capability in adverse weather conditions. It disposes of higher resolution, more accuracy, nocturnal mode, and faster data transfer capability. At the outset, France was the project's only sponsor, but in 2001, Belgium and Spain joined to contribute together about 6 percent of the total costs, about 120 million Euros of the total 2280 million. ${ }^{67}$

CSO Project: A few states planned to produce Helios 3A and 3B by 2012 or 2013. However, budgetary difficulties forced the cancelation of the project. France decides to continue on its own and labels the project CSOtranslated from French, meaning Optical Space Component. After long and arduous bargaining with the Germans, France agreed to fund about 200 million Euros of CSO satellite. The Germans will not be involved in the production process. Sweden is also a participant in the program. It will provide a polar ground station. This project should improve the timeliness of the data significantly, so crucial during military operations. ${ }^{68}$ 


\section{Conclusions: Economic Imperatives and Bandwagon Alignment Strategy}

The article explained the concept of market imperfections. It analyzed a few NATO projects to show that gains and costs savings from multinational cooperation, given market imperfections and cost sharing, are sizeable and produce technological spillover effects to other industrial areas of the national economies. NATO states are more likely to continue and strengthen military-technological cooperation in the presence of market imperfections - to save costs-even if they face a minimal external threat. The great European and North American powers appear to have benefited from joint projects. By taking advantage of market imperfections, they preserved and even increased power capabilities despite spending less.

General review and analysis of available data suggest that the political economy of military production is an essential causal variable in the alliance politics among great powers. The study elucidates why states continue to ally in the absence of external threats. Moreover, it suggests that Schweller's logic in the theory of balance-of-interests is generally valid, mainly when taking into consideration economic variables that can also explain military cooperation of great powers in times of peace. On a larger scale, the study demonstrates that the incorporation of politicaleconomic variables enriches the realist theory on military alliance dynamics.

The study suggests that military power has a unique quality. It can increase exponentially in ratio to inputs. This finding is important because states might decide to cooperate in the amassing of this power by pulling their resources together. Following this multilateral approach, they can generate more power, using fewer resources, than by pursuing a single tactic. Moreover, cooperation would make sense even if states would want to generate the same amount of power accessible on their own, only because it would cost them significantly less. Hence, the study suggests that the logic of Schweller's balance-of-interest thesis works in times of peace as well. Status quo powers will cooperate, and they do not need external threats to do so as long as there remains the possibility of gains in the form of economic incentives. In closing, it appears from the above discussion that as long as states' interests are compatible and economic 
calculations and incentives remain strong and viable; these will bind great powers together in internal and continued collaboration for the sake of obtaining and maximizing gains beyond political, ideological, and national security objectives.

\section{Endnotes}

${ }^{1}$ Glenn H. Snyder, “Alliance Theory: A Neorealist First Cut," Journal of International Affairs 44, no. 1 (1990):104, https://doi.org/10.1017/S0020818300001417.

2 Barry R. Posen, "Trump Aside, What's the U.S. Role in NATO?," New York Times March 10, 2019, https://www.nytimes.com/2019/03/10/opinion/trump-aside-whats-the-us-role-innato.html?action $=$ click\&module $=$ Opinion\&pgtype $=$ Homepage .

${ }^{3}$ John J. Mearsheimer, "Why We Will Soon Miss The Cold War;" The Atlantic Monthly 266, no. 2; (August 1990): 35-50, https://www.theatlantic.com/past/docs/politics/foreign/mearsh.

${ }^{4}$ Wallace J. Thies, Why NATO Endures (New York: Cambridge University Press, 2009), 25-86, https://dl1.cuni.cz/pluginfile.php/487123/mod_resource/content/1/Wallace\%20J.\%20ThiesWhy\%20NATO\%20Endures\%20\%282009\%29.pdf.

${ }^{5}$ Mearsheimer, "Why We Will Soon Miss The Cold War."

${ }^{6}$ Mancur Olson, and Richard Zeckhauser, "An Economic Theory of Alliances," The Review of Economics and Statistics 48, no. 3 (1966): 266-79, http://doi.org/10.2307/1927082. https://www.cambridge.org/us/academic/subjects/politics-international-relations/internationalrelations-and-international-organisations/why-nato-endures?format=HB\&isbn=; and Todd Sandler, "The Economic Theory of Alliances: A Survey," The Journal of Conflict Resolution 37, no. 3 (1993): 446-83, https://doi.org/10.1177/0022002793037003003.

${ }^{7}$ Brett Ashley Leeds, and Burcu Savun, "Terminating Alliances: Why Do States Abrogate Agreements?," The Journal of Politics 69, no. 4 (2007): 1118-132, https://doi.org/10.1111/j.1468-2508.2007.00612.x.

${ }^{8}$ Kenneth N. Waltz, "NATO Expansion: A Realist's View," Contemporary Security Policy 21, no. 2 (2000): 23-38, https://doi.org/10.1080/13523260008404253; David A. Lake, Entangling Relations: American Foreign Policy in Its Century (Princeton, NJ: Princeton University Press, 1999), https://press.princeton.edu/books/paperback/9780691059914/entangling-relations.

9 Vincent Pouliot, "Regional Security Practices and Russian-Atlantic Relations," in T.V. Paul, ed., International Relations Theory and Regional Transformation (Cambridge and New York: Cambridge University Press, 2012): 210-229, www.cambridge.org/9781107604551.

${ }^{10}$ Steven Weber, "A Modest Proposal for NATO Expansion," Contemporary Security Policy 21, no. 2 (2000): 91-106, https://doi.org/10.1080/13523260008404257.

${ }^{11}$ Jonathan Sireci and Damon Coleta, "Enduring Without an Enemy: NATO's Realist Foundation," Perspectives 17, no. 1 (2009): 57, https://www.ceeol.com/search/articledetail id $=227660$.

${ }^{12}$ Mike Sweeney, "What is NATO Good For?” The Strategy Bridge, January 6, 2020 https://thestrategybridge.org/the-bridge/2020/1/6/what-is-nato-good-for.

${ }^{13}$ Brett Ashley Leeds, Michaela Mattes and Jeremy S. Vogel, "Interests, Institutions, and the Reliability of International Commitments," American Journal of Political Science 53, no. 2 (April 2009): 461-476, https://doi.org/10.1111/j.1540-5907.2009.00381.x.

${ }^{14}$ Trine Flockhart, "NATO and the (Re-) Constitution of Roles: 'Self,' 'We' and 'Other'?" Danish Institute for International Studies, 2010, www.jstor.org/stable/resrep13413.

${ }^{15}$ Mordecai Roshwald, "NATO-Where To?" International Journal on World Peace 15, no. 3 (1998): 45-53, https://www-jstor-org.ezproxy.fiu.edu/stable/20753167.

${ }^{16}$ Felix Ciutā, "The End(s) of NATO: Security, Strategic Action and Narrative Transformation," Contemporary Security Policy 23, no. 1 (2002): 35-62, https://doi.org/10.1080/713999727.

${ }^{17}$ John Duffield, "NATO's Functions after the Cold War," Political Science Quarterly 109, no. 5 (Winter 1994-1995): 763- 787, https://doi.org/10.2307/2152531; Robert Kagan, “America's Crisis of Legitimacy," Foreign Affairs 83, no. 2 (March/April, 2004): 6, 
http://doi.org/10.2307/20033903; Vojtech Mastny, "The New History of Cold War Alliances," Journal of Cold War Studies 4, no. 2 (Spring 2002): 55-84, https://www.mitpressjournals.org/doi/abs/10.1162/152039702753649647; Celeste Wallander and Robert Keohane, "Risk, Threat, and Security Institutions," in Helga Haf-tendorn, Robert Keohane, and Celeste Wallander, eds., Imperfect Unions: Security Institutions over Time and Space (Oxford, UK: Oxford University Press, 1999): 21-47, https://global.oup.com/academic/product/imperfect-unions-9780198207962?cc=us\&lang=en\&\#.

${ }^{18}$ Keith Hartley and Todd Sandler, "NATO Burden-Sharing: Past and Future," Journal of Peace Research 36, no. 6 (November 1999): 665-680, https://doi.org/10.1177/0022343399036006004.

${ }^{19}$ Jonathan Kirshner, "Realist Political Economy, Traditional Themes and Contemporary Challenges, in Mark Blyth, ed. Routledge Handbook of International Political Economy (IPE): IPE as a Global Conversation (New York: Routledge, 2009): 37, https://www.routledge.com/Routledge-Handbook-of-International-Political-Economy-IPE-IPEas-a-Global/Blyth/p/book/9780415781411.

${ }^{20}$ As quoted by Kirshner, "Realist Political Economy," 37.

${ }^{21}$ Kenneth N. Waltz, Theory of International Politics (Reading, Massachusetts: Addison-Wesley Publishing Company, 1979): 129-160.

${ }^{22}$ Jean-Marc F. Blanchard, Edward D. Mansfield and Norrin M. Ripsman, eds., Power and the Purse: Economic Statecraft, Interdependence and National Security (New York: Routledge, 2000), https://doi.org/10.4324/9781315038476.

${ }^{23}$ Stephen M. Walt, The Origins of Alliances (Ithaca: Cornell University Press, 1990): 54.

${ }^{24}$ Randall L. Schweller, "Bandwagoning for Profit: Bringing the Revisionist State Back In," International Security 19, no. 1 (1994): 80, http://doi.org/10.2307/2539149.

${ }^{25}$ Schweller, "Bandwagoning for Profit," 81.

${ }^{26}$ Dale C. Copeland, "Economic Interdependence and War: A Theory of Trade Expectations," International Security, 20, no. 4 (Spring, 1996), pp. 5-41, http://doi.org/10.2307/2539041.

${ }^{27}$ Nuno P. Monteiro, "Unrest Assured: Why Unipolarity Is Not Peaceful," International Security, 36, No. 3 (Winter 2011/12): 9-40, www.jstor.org/stable/41428108.

${ }^{28}$ George Liska, Nations in Alliance: The Limits of Interdependence (Baltimore: The Johns Hopkins University Press, 1962); Ole R. Holsti, P. Terence Hopmann and John D. Sullivan, Unity and Disintegration in International Alliances: Comparative Studies (New York: John Wiley, 1973); Stefan Bergsmann, "The Concept of Military Alliance," in Erich Reiter and Heinz Gärtner eds. Small States and Alliances (New York: Springer-Verlag Berlin Heidelberg, 2001): 25-37, https://doi.org/10.1007/978-3-662-13000-1; Walt, The Origins of Alliances.

${ }^{29}$ Paul R. Krugman and Robin Wells, Macroeconomía (Barcelona, Spain: Editorial Reverté, 2016): 25.

${ }^{30}$ George DeMartino, Global Economy, Global Justice: Theoretical Objections and Policy Alternatives to Neoliberalism (London: Routledge, 2000): 70, www.jstor.org/stable/29770232.

${ }^{31}$ Alfred D. Chandler, The Visible Hand: The Managerial Revolution in American Business (Cambridge, MA: Belknap Press, 2002): 92.

${ }^{32}$ Ragnar Frisch, Theory of Production (Dordrecht: Holland, D. Reidel Pub. Co., 1965): 78.

${ }^{33}$ Frisch, Theory of Production, 85.

${ }^{34}$ David J. Teece, "Scope of the Enterprise," in Mie Augier and David J. Teece, eds., The Palgrave Encyclopedia of Strategic Management (London, U.K.: Palgrave Macmillan, 2018): 225.

${ }^{35}$ Teece, "Scope of the Enterprise," 230.

${ }^{36}$ Alfred Greiner and Horst Hanusch, Endogenous Growth Cycles Arrows Learning by Doing Reconsidered (Augsburg: Inst. für Volkswirtschaftslehre, 1994): 28.

${ }^{37}$ Lucas Bretschger, Growth Theory and Sustainable Development (Cheltenham, UK: Edward Elgar, 1999): 85.

${ }^{38}$ Bretschger, Growth Theory and Sustainable Development, 105.

${ }^{39}$ Bretschger, Growth Theory and Sustainable Development, 122.

${ }^{40}$ Norman R. Augustine, Augustine's Laws and Major System Development Programs, Sixth Edition, (Reston, VA: American Institute of Aeronautics and Astronautics, Inc., 1997): 18, https://doi.org/10.2514/4.868832.

${ }^{41}$ Augustine, Augustine's Laws, 19. 
${ }^{42}$ Augustine, Augustine's Laws, 38.

${ }^{43}$ Defence and Peace Economics, 83.

44 “PESCO, Member States Driven," https://pesco.europa.eu/.

${ }^{45}$ Harold Asher, "Cost-Quantity Relationships in the Airframe Industry," (RAND Corporation, January 1, 1956): 28.

${ }^{46}$ Asher, "Cost-Quantity Relationships," 12.

${ }^{47}$ Asher, "Cost-Quantity Relationships," 28.

${ }^{48}$ Keith Hartley and Todd Sandler, Handbook of Defense Economics (Amsterdam, Holland: Elsevier, 1995): 28.

${ }^{49}$ Hartley and Sandler, Handbook of Defense Economics, 28.

${ }^{50}$ Stefan Markowski, Peter Hall, and Robert Wylie, Defence Procurement and Industry Policy: A Small Country Perspective (London: Routledge, 2014): 125.

${ }^{51}$ Richard Bitzinger, The Modern Defense Industry: Political, Economic, and Technological Issues (Santa Barbara, CA.: Praeger Security International, 2009): 35.

${ }^{52}$ Michael Peck, "F-35 vs. the Rest: Which of These 5 Planes Will Be Canada's New Fighter Jet?" The National Interest, November 11, 2018, at https://nationalinterest.org/blog/buzz/f-35-vs-restwhich-these-5-planes-will-be-canadas-new-fighter-jet-35717.

${ }^{53}$ Keith Hartley, "The Eurofighter Development Programme," Air \& Space Europe 1, no. 3 (1999): 13, https://doi.org/10.1016/s1290-0958(00)87073-2.

${ }^{54}$ Hartley, "The Eurofighter Development Programme," 23.

${ }^{55}$ Hartley, "The Eurofighter Development Programme," 29.

${ }^{56}$ Keith Hartley and Todd Sandler, "The Future of the Defense Firm," Kyklos 56, no. 3 (2003): 28, https://doi.org/10.1046/j.0023-5962.2003.00225.x.

${ }^{57}$ Eurofighter Typhoon, “The Industrial and Economic Benefits of Eurofighter” (2018), 56, https://world.eurofighter.com/articles/the-european-project; Markus N. Heinrich, "The Eurofighter Typhoon Programme: Economic and Industrial Implications of Collaborative Defence Manufacturing," Defence Studies 15, no. 4 (2015): 341-360, https://doi.org/10.1080/14702436.2015.1113668.

${ }^{58}$ Keith Hartley, "The future of European Defence Policy: An Economic Perspective" Defence and Peace Economics 14, no. 2 (2003): 43, https://doi.org/10.1080/10242690302921.

${ }^{59}$ Hartley, "The future of European Defence Policy," 46.

${ }^{60}$ Keith Hartley, "White Elephants? The Political Economy of Multi-National Defense Projects," Security and Defence Management, January 01, (1970): 13.

${ }^{61}$ Hartley, "White Elephants? The Political Economy," 13.

${ }^{62}$ Hartley, "White Elephants? The Political Economy," 16.

63 "Ministry of Defence: Maximising the Benefits of Defence Equipment Co-Operation-National Audit Office (NAO)," National Audit Office, https://www.nao.org.uk/report/ministry-ofdefence-maximising-the-benefits-of-defence-equipment-co-operation/.

${ }^{64}$ National Audit Office, "Ministry of Defence: Maximising the Benefits."

65 "Helios 1A, 1B," Gunter's Space Page-Information on spaceflight, launch vehicles and satellites, accessed January 14, 2018 http://space.skyrocket.de/doc_sdat/helios-1a.htm.

66 "Helios 1A, 1B."

67 "Helios II," accessed January 14, 2018, http://www.deagel.com/Space-Systems/HeliosII_a000258002.aspx.

${ }^{68}$ Gosnold, "History of the French Reconnaissance System," Satellite Observation, November 6, 2017, https://satelliteobservation.wordpress.com/2016/11/06/history-of-the-frenchreconnaissance-system/. 